\title{
The Role of Teacher and Organizational Culture in School Management
}

\author{
Dinko Jukić \\ Trade and Commercial School "Davor Milas", Osijek, Croatia \\ https://orcid.org/0000-0002-5595-4245
}

\begin{abstract}
The paper discusses and analyses the importance of employees in the context of school management. The construct of organizational culture is observed using an interdisciplinary approach from the aspect of management, marketing, and educational sciences. The role of the employee as a key arbiter of organizational culture and promoter of the organization itself is discussed. The levels of school culture, its specifics, and functions in the context of a non-profit organization are presented. The role of employees is analysed from two aspects, the creation of corporate identity and the aspect of strengthening employee beliefs, and self-image, and emphasizes its importance for creating the identity of the organization, organizational culture, and climate. The analysis of the literature raised questions about the importance of employees in creating an organizational culture, but also in creating a corporate image and identity. Different approaches to the function of organizational culture, levels of school culture and types of school climate, school identity, and the role of management are considered. The place of employee satisfaction, employee identity and the creation of organizational culture are critically observed, and suggestions are given on how to improve school management. The concluding part emphasizes that employees are the most important resource of any organization and that satisfied employees create an open and positive organizational climate, create the identity of the organization, and provide better service.
\end{abstract}

\section{Keywords}

teacher, teacher's identity, organizational culture, school culture, school management

\section{Introduction}

Organizations consist of members (Guion, 2011, p. 3 ) and it is these members that form the core of any organization. Organizations change, develop, grow, and fail. In fact, everything is changing. Employees retire, change jobs, or leave the organization. Changes are a constant of every organization and connecting them to the famous phrase of the Greek philosopher Heraclitus Panta $R h e i$ we can conclude that all things are flowing indeed.

The construct of organizational culture (OC) is important for understanding the basic concepts and characteristics in school management (SM). The concept itself is not new and has foundations in sociology and anthropology (Ployhart, Hale \& Campion, 2014, p. 26). Research on the OC construct dates to 1938 (Hoy \& Miskel, 2012, pp. 179-185). Although the OC construct is accepted, there is no precise definition. The reason for this stems from the complexity of the very notion of culture (Williams, 2015, p. 87) which is difficult to define.

Organizational culture, climate, and staffing form a symbiotic relationship in most every place except one: the academic literature (Ployhart et al., 2014 , p. 23). The situation is no better in the context of educational management and SM. OC schools are not easy to define because they encompass organizational values, employee

\footnotetext{
${ }^{1}$ Extended version of the paper presented at Strategic Management and Decision Support Systems in Strategic Management SM 2021 scientific conference.
} 
behaviour, and shared attitudes. OC acts on management because it motivates employees.

Observing the phenomenon of school climate from the economic aspect, more precisely, from the field of management and marketing, it can be realized that the concept of school climate can be equated with the concept of OC. The role of school culture, as well as the climate, is very important for further understanding because it depends on building the reputation of the school or building an identity that consequently leads to the construction of the image.

Schools are open social systems with five important elements: the structural, the individual, the cultural, the political, and the pedagogical (Hoy $\&$ Miskel, 2012, p. 1). The importance of OC in contemporary management has been much debated (Deshpande \& Webster, 1989, p. 4; Bolam, 1999, p. 196; Deshpande, Farley \& Webster, 1993, p. 25; Deshpande \& Farley, 2004, p. 13; Slater, Olson \& Finnegan, 2011, p. 229; Song, Kim \& Kolb, 2009, p. 162) and there are numerous definitions of OC. From the aspect of non-profit marketing (Andreasen \& Kotler, 2008, p. 42-51) and educational management (Bush, 2003, pp.37-38; Bush, 2007, p. 394), OC represents the starting point of strategic employee analysis.

The topic of this paper is a review and analysis of school culture, school climate, employees and their importance in SM and corporate marketing. However, the aim of the paper is not to answer questions about the importance of school culture and employees, but to offer a framework for further interdisciplinary analysis and discussion.

The paper consists of two parts. The first part discusses organizational culture and its impact on school development. It analysed the specific functions of school culture, OC levels and its components. The second part analyses the school climate and SM. The starting point is the construct of employee self-image and identity. We also show the role of teachers during the COVID-19 pandemic.

\section{Levels of school culture}

$\mathrm{OC}$ is a key concept in contemporary management. Some authors (Parker, 2000, p. 187-189) hold that OC reflects a long-standing tension between the cultural and structural versions of what organizations are. OC can also be understood as a metaphor of the corporation (Alvesson, 2002, p. 38 ) in which a place is opened for the analysis of the corporate image.
OC occupies a central place in contemporary management (Huczynski \& Buchanan, 2007, p. 623). The OC itself is permeated in all aspects of SM. It affects the type of corporation structure, the way it is organized, the type of power, the way it is decentralized, the way it controls, the strategy of the organization, human resource management, and resource allocation. School culture plays an important role in the development of an organization.

School culture, as a kind of version of OC, should be viewed from the aspect of leadership (Kızıloğlu, 2021, p. 831; Nowak, 2020, pp. 487489 ) and in this sense analyse how school leadership is reflected on employees and stakeholders in the educational process. However, such a culture always exists in two relations: the one that the average user sees and the one that is not seen.

The school climate together with the school culture forms an important segment of the psychosocial functioning of the school. Thus, the school climate represents the totality of employee togetherness in their aspirations, sense of belonging to the teaching council, all the way to the motivational components.

The processes that each school goes through in search of effectiveness presents the organization as a cultural and educational institution. Understanding OC is a vital part of improving school quality (Stoll \& Fink, 1996, p. 116). Table 1 shows specific characteristics of school culture.

Table 1. Specific functions of school culture

\begin{tabular}{l|l}
\hline Area & Impact \\
\hline School Performance & Employees \\
\hline Instrument of realization & School management (SM) \\
\hline Control system & Principal \\
\hline Psychological space & Corporate brand \\
\hline Identity of the school & Identity of the employee \\
\hline Employee motivation & Principal \\
\hline Employee identity & Organizational culture (OC) \\
\hline
\end{tabular}

Source: the author

As can be seen from Table 1, the specific functions of school culture can be observed through the areas in which they occur and through the impact on the organization. It is interesting that the identity of employees is at the same time an area that is related to school culture, but also has an impact on OC. This means that the connection between behaviour and culture is two-way, i.e., that it appears as a cause, but also as a consequence. 
The control system is a specificity of OC and represents the strongest and largest model of control (Mullins, 2006, p. 474) implemented by the principal in SM. A specific distinctive, psychological space ensures the integrity and determines the identity of the organization, but also opens the way to the development of the school's corporate brand (Jukić, 2017, p. 15). The school identity also realizes the identity of the employee. It is also a very complex construct because the identity of the teacher is closely linked to school culture (Flores \& Day, 2006, p. 230; Jukić, 2019, p. 15) and school identity.

School culture is difficult to define because it encompasses: the value of the organization, employee behaviour, rituals, norms, common attitudes, philosophy, and overall perception of the organization. However, such attitudes and beliefs are subconscious (Schein, 1985, p. 6), which means that OC represents the way employees work (Schneider, Gonzalez-Roma, Ostroff, \& West, 2017, p. 468). In essence, school culture is intertwined with employees, organization, and school identity.

Therefore, metaphors, symbols, rituals, customs, and myths create school culture. From such an aspect, the only thing that is important is to understand the importance of school culture and to know how to manage it (Schein, 1985, p. 2). From a managerial perspective, the most important function of $\mathrm{OC}$ stems from raising individual and organizational performance.

Finally, school culture can be viewed as a teacher workplace environment that is formulated from interactions with other employees. The complexity of school culture is indicated by many elements, as well as the fact that there are differences from one organization to another. The intensity of the presence of $\mathrm{OC}$ dimensions (Robbins \& Coulter, 2005, p. 52) can be rated from low to high.

However, in SM, evaluating school culture is very ungrateful. Schools may emphasize an innovative approach to teaching or service quality, some seek to maintain a stable reputation by avoiding change or risk, some may foster a team approach, promote collaboration with other cultural institutions, and some may be employeeoriented and considered central to school culture.

That is why the school culture is a group of elements of visibility. The model of culture (Schein, 1985, p. 14) encompasses three cognitive levels that differ in their visibility and accessibility: a) external manifestations of culture, b) values of school culture, and c) fundamental assumptions of school culture. Table 2 shows the levels of school culture.

Table 2. Levels of school culture

\begin{tabular}{l|ll}
\hline Cognitive level & School culture & \\
\hline Events & $\begin{array}{l}\text { School products (trophies, commendations, } \\
\text { library) }\end{array}$ \\
\hline Values & $\begin{array}{l}\text { Teacher's relationship (rituals, myths, } \\
\text { ceremonies) }\end{array}$ \\
\hline Assumptions & Core value (norms, values, identity) & \\
\hline
\end{tabular}

Source: the author

The first level of school culture constitutes the external manifestations of culture and refers to the visible "products" that the school has. Specifically, these are: offices, equipment, furniture, symbols, and the way employees communicate with each other. These are "products" that convey the message of school culture and at the same time, the most accessible form of school culture. The notion of product should be understood here conditionally because schools provide service, and through their tangible elements they manifest products. Of course, school products then communicate on an integrated marketing communication, on symbols, metaphors, and the way they interact with each other.

The second level, which is less visible, makes values that create a broad framework of employee behaviour that reveals the preferences of certain solutions and attitudes within the school. These values can be implicit or explicit; specifically, the employee's relationship to external associates or to each other's, and are manifested in the celebration of specific events of the organization. Employee behaviours reveal indirect attitudes and worldviews.

And finally, the third level represents the deepest, fundamental assumption of school culture. These are unwritten rules, norms, and values that employees are usually not aware of, but respect and accept as given values of the school itself.

These invisible, deeply hidden values represent the paradigms of SM (Wallace \& Weindling, 1999, pp. 206-208) because they act as a filter that influences the way employees observe and behave. Simply put, it is the core of school culture and affects all perceptions of employees, stakeholders, and society.

Having in mind the components of school culture and its causal relationship to the teacher's job satisfaction, as well as to school efficiency, school culture, simplified, can be viewed as a positive and negative culture. A positive environment reflects employee participation in 
joint activities, appreciation, sharing of responsibilities, and a shared vision of the school.

Clan cultures are most strongly associated with positive employee attitudes (Hartnell, Ou \& Kinicki, 2011, p. 684). Teachers in the context of SM represent a form of clan culture. Organizations succeed because they hire, develop, and retain their human resource base (Cameron, Quinn, DeGraff, \& Thakor, 2006, p. 38).

We can present a negative environment as an unhealthy climate, non-acceptance of new methods of work, tendency to criticize, incompetence and avoidance of responsibility. In the following, we present school culture according to Peterson and Costner (2006, p. 250) components, and they are visible in Table 3.

Table 3. Components of school culture

\begin{tabular}{l|l|l|l}
\hline \multicolumn{1}{c|}{ Frames } & \multicolumn{1}{c}{ Products } & Expressions & Activity \\
\hline $\begin{array}{l}\text { Norms (dress } \\
\text { code, } \\
\text { collegiality) }\end{array}$ & $\begin{array}{l}\text { Trophies } \\
\text { (school } \\
\text { competitions) }\end{array}$ & $\begin{array}{l}\text { Stories } \\
\text { (remembrance } \\
\text { of school } \\
\text { success) }\end{array}$ & $\begin{array}{l}\text { Rites } \\
\text { (school } \\
\text { routines) }\end{array}$ \\
\hline $\begin{array}{l}\text { Values } \\
\text { (student } \\
\begin{array}{l}\text { achievement, } \\
\text { expertise) }\end{array}\end{array}$ & $\begin{array}{l}\text { Commendations } \\
\text { (research } \\
\text { achievements) }\end{array}$ & $\begin{array}{l}\text { Myths } \\
\text { (idealization of } \\
\text { school } \\
\text { success) }\end{array}$ & $\begin{array}{l}\text { Rituals } \\
\text { (marking } \\
\text { specific } \\
\text { events) }\end{array}$ \\
\hline $\begin{array}{l}\text { Certificates } \\
\text { (success at } \\
\text { graduation, } \\
\text { final theses) }\end{array}$ & Library & Alumni \\
(services) & (contact) & $\begin{array}{l}\text { Ceremonies } \\
\text { (events) }\end{array}$ \\
\hline
\end{tabular}

Source: adapted according to Peterson \& Costner, 2006, p. 250

School culture consists of frameworks, products, expressions, and activities. The frameworks encompass the norms and beliefs of the school and are integrated into the values of the school itself. From a symbolic point of view, the products represent the value of the school. This specifically means that the school uses a variety of artefacts in the form of trophies, awards, medals, and even a library to show the school culture.

This is a classic hybrid view of service marketing (Grönroos, 2020, p. 295) in which the intangibility of school service is displayed through elements of school culture. And finally, two components remain: expressions and activities. The terms encompass school beliefs that are deeply interwoven with tradition and school success stories. This is especially evident in the realization of school ceremonies when the myth of the school and positive cases that serve as employee motivation are considered.

Finally, there are activities that represent school rituals. Rituals can be understood as a school routine that accompanies appropriate ceremonies. Also, all forms of ceremonies, performances and events are part of school culture.

Why is corporate marketing important in SM? SM starts from two key elements: the manager and the employee. The school principal represents a manager who decides, leads, and organizes everything related to the economics of education, such as funding, administrative work, enforcement of pedagogical standards, compliance with the law, employee education, service delivery and impact on school development in the broadest sense.

As can be seen, employees are a key element in corporate marketing, especially in creating positive impressions towards the services provided, the identity of the organization and the overall image. Employees are the main service providers and the first, initial stage of the organization. They represent, symbolize, and promote school, service, and ultimately, education.

The school climate develops through the relationship between employees and the entire organization, and the school culture emerges as a product of employee work over a period. Such a culture is connected through employee norms and beliefs (Lee, 2020, p. 68). Simply put, school culture is a deep structure of organizations, which is rooted in the values and beliefs held by teachers while school climate is rooted in the organization's value system.

School culture, once formed, is "petrified" (Stoll \& Fink, 1996, p. 119). In the broadest sense of the word, school culture, once formed, becomes the production process of the school. However, school culture is also a paradoxical phenomenon because, once created as a process, it is in constant change. This means that with the arrival of new employees, it gradually changes, because employees change as well as opportunities in society. Thus, school culture is a long process of producing the image of the organization. It is a process of evolution which, despite its peculiarities, components and levels, represents a static and dynamic phenomenon.

\section{School climate and SM}

We understand the school climate as a way for an employee to perceive everything that happens at school. The school climate plays a very significant role in shaping employee behaviour and influencing their attitudes about knowledge management. Therefore, the importance of the school climate is twofold: on the one hand it encourages an innovative atmosphere and thus 
becomes part of the internal processes of the organization, and on the other hand, by creating employee identity, allows creating a school identity, i.e., creating a corporate brand.

School climate can be observed according to the dimensions of organizational climate (Halpin, 1966 , p. 150). With such an understanding, we analyse the school climate through the behaviour of employees and managers.

Teacher behaviour can then be classified as a) non-engaged; b) burdened; c) satisfied and d) intimate. The first group, non-engaged, represents teachers who perform their tasks superficially and disinterestedly. The metaphor of the burdened represents teachers who are burdened by the principal with administrative and additional tasks. The satisfied group represents a category of teachers who enjoy a sense of achievement. The last group comprises intimate employees who enjoy a friendly environment.

From the aspect of the principal's behaviour, we observe the dimensions of the school climate as: a) restrained; b) productive; c) exemplary and d) considerate. A group of restrained principals represents the formal behaviour of a principal who is distanced. Productive principals are characterized by constant control of teachers; their communication is one-way. The third group consists of exemplary directors who motivate employees and build trust. Finally, the latter group represents considerate principals characterized by a willingness to communicate and assist.

From these dimensions we can conclude that the effectiveness of the school and the school climate is simply seen as an open and closed climate. The open climate (Halpin, 1966, p. 174) represents the cooperation of teachers and principals who are not burdened by the administration and ultimately, are proud of their organization. A closed climate (Halpin, 1966, p. 180) refers to an inefficient director who does not care about the needs of employees. The types of school climate are shown in Figure 1 according to Hoy, Tarter \& Kottkamp (1991, p. 40).

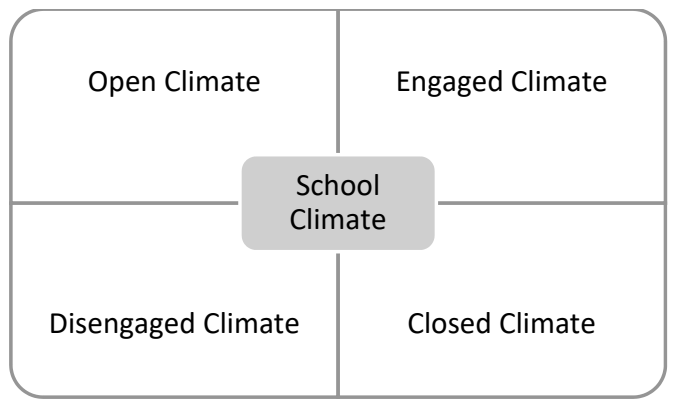

Figure 1 Types of school climate

Source: adapted according to Hoy et al., 1991, p. 40

It is important to note that for the proper implementation of these types of school climate, it is necessary to analyse them in accordance with the Cartesian coordinate system. The ordinate (vertical) axis then represents the behaviour of the employee, and the abscissa (horizontal) the behaviour of the manager. Therefore, we distinguish four types of school climate: open, engaged, non-engaged and closed.

An open climate represents respect and cooperation of employees and managers. An engaged climate is an open-closed combination, i.e. inefficient directors and efficient employees. This means that this is a restrictive and authoritative manager, but the organization is still collegial. A non-engaged climate is the opposite of an engaged one, so it's a closed-open combination. The manager then supports the employees, but the employees do not take responsibility. This means that they do not agree and do not respect each other. Finally, a closed climate is the opposite of an open climate: a manager does not support employees, and employees do not respect each other and are dissatisfied.

If, we look at the relationship between school culture and school climate from the aspect of affiliation, we look at school culture from a sociological and anthropological aspect because it questions deeper teacher relationships, while school climate belongs to the field of psychology because it represents its manifestation on individuals. It is interesting to note that the role of school culture is closely related to the managerial skills of the school itself. OC has been shown to affect employee performance which is reflected in their satisfaction and efficiency (Morris \& Bloom, 2002, p. 71-83).

According to a study of the relationship between school culture by teacher satisfaction and school efficiency (Duan, Du \& Yu, 2018, pp. 15$25)$, the results confirm the correlation between school culture, satisfaction, and efficiency. 
Regression analysis confirms that teacher satisfaction plays a mediating role in the relationship between school culture and school efficiency. School culture has been shown to form a collective relationship, ceremonies and events form an integral part of school effectiveness (Duan, et al., 2018, p. 21).

\subsection{Teacher identity}

Principals have an important part in building school culture as well as creating an organization's identity. Their impact strongly influences employee motivation and efficiency (Day, Kington, Stobart \& Sammons, 2006, p. 605). Also, principals who support their employees build an environment for a favourable climate and culture. Employees who work in schools where they are supported and encouraged by principals show positive attitudes toward teaching (Flores \& Day, 2006, p. 230), but also greater loyalty to the organization. However, to be able to talk about the identity of the school at all, we must first briefly explain the identity of the teacher.

The identity of the teacher can be most simply presented as the teacher's sense of self-worth and reflection on those values. The identity of the teacher is not a constant and stable phenomenon and, in addition to its characteristics, depends on the work, life context and relationships with others. Teacher identity involves a mixture of personal, professional, and situational factors (Granjo, Silva $\&$ Peixoto, 2021, p. 161). The concept of ethical dimension implies honesty, fairness, respect, and kindness in interacting with students. Ethical orientation is a key factor in a teacher's identity (Granjo et al., 2021, p. 169).

The key questions that arise in defining a teacher's identity are: who am I as a teacher and what kind of teacher do I want to be? The beliefs and values of the teacher develop from his personal attitudes, experiences, social environment, and the environment in which he lives. Teacher beliefs are acquired at an early age and they are deeply rooted. Korthagen $(2004$, p. 80 ) argues that professional identity is made of unconscious needs, feelings, values, role models, previous experiences, and behaviours, which together create a sense of identity.

Teachers are in the constant dynamics of school events, and by interacting with the environment, they participate actively in the process of shaping and self-shaping. However, the teacher's identity can be viewed from the perspective of the employee, but also from the perspective of the stakeholders.

Teachers define and realize their identity through self-image, attitudes, relationships with other employees, school culture and the service provided. From the perspective of stakeholders, we look at the teacher's identity from the perspective of service quality, behaviour, and pedagogical competencies. Therefore, to understand employee identity better (Holland \& Lachicotte, 2007, p. 123) in SM, it is crucial to encompass the context of society, organization, and culture.

Learning to become an effective teacher is a long and complex process (Flores \& Day, 2006, p. 219). The school climate affects the emotional state of employees. Teacher's feelings of vulnerability engendered when identity is questioned by policy changes, inspectors, or colleagues (Kelchtermans, 1996, p. 321). The shape and reshape teacher's identity study presented three influences (Flores \& Day, 2006, p. 223): a) past experience, b) motivation and c) school culture.

It was confirmed that school culture and climate play an important role in creating the identity of the employees and affect their quality of service and job satisfaction. Being a proper teacher implies the social recognition of both one's technical skills and competencies and one's moral integrity (Kelchtermans, 1996, p. 318).

Interestingly, most employees describe their first experience within SM as stressful (Flores \& Day, 2006, p. 225), and the difficulties they cite are a bureaucratic burden and an overload of responsibilities. The impact of the school climate plays a key role in employee reshaping. Consequently, self-knowledge is an important element in the way employees perceive their role.

The teacher's identity is not only created by the technical and emotional aspect of teaching, but also as a result of personal experience, school culture and school climate. The employee's identity can be observed through five categories (Kelchtermans, 1993, p. 449) which we show in Table 4.

Table 4. Teacher identity self

\begin{tabular}{l|l}
\hline $\begin{array}{l}\text { The image of the } \\
\text { employee }\end{array}$ & Impact on school management \\
\hline Self-image & Employee image \\
\hline Self-esteem & Quality of service provided \\
\hline Job-motivation & Loyalty to the organization \\
\hline Task perception & Satisfaction with the organization \\
\hline Future perception & Expectations from the organization \\
\hline
\end{tabular}

Source: adapted according to Kelchtermans, 1993, pp. 449-450 
In this context, we understand the self-image as the perception of employees that manifests itself through their work. It is a psychological construct that shows the employee's attitude towards work, but, from the aspect of the employee, also his identification at work. Self-esteem represents the perception of the employee as a teacher (his quality), while job-motivation represents the degree of loyalty to the organization.

In other words, we can analyse self-esteem from the aspect of SM and analysis of the service provided, i.e., the perception of quality. Of course, job motivation in the context of brand management (Kapferer, 2008, p. 171-197) can also be interpreted as loyalty to the organization. It is this loyalty to the organization that is outlined in satisfaction, expectation, sacrifice, and motivation. Task perception represents how teachers define their jobs.

This means that satisfaction with the organization makes a very similar construct to the brand attachment because it shows managers two key determinants: the degree of loyalty and satisfaction. An employee does not have to be loyal to be satisfied and vice versa. An employee may be dissatisfied with the job for various reasons such as salary, working conditions, but also loyal to the organization because he still works and does not endanger the image.

And finally, the future perspective makes the employee's expectations. The construct of his expectations is a turning point that separates motivation from satisfaction because expectations are a consequence of the school climate. As can be seen, the employee's self in SM, but also in corporate marketing, can serve as an analytical model.

From the above, we can present two key hypotheses of employee identity in SM: stability and vulnerability. Stability at work depends on loyalty to the organization, satisfaction with the organization and expectations from the organization. Vulnerability at work depends on the first two categories of employee identity (Table 4), i.e. how satisfied the employee is with his reputation in the school, society, working conditions, service provided and all stakeholders of the organization. Obviously, the architecture of employee identity is not a stable construct (Day et al., 2006, p. 613).

An analysis of the organization's climate will show whether the school's climate needs to change or fit into the organization's existing culture. According to Stacey (1993, pp. 41-45) the nature of an organization's culture can be analysed through the power structure of the organization. Power comes from the relationships that emerge over time between individuals and groups. The source of power is related to the form it takes. Power in SM takes the form of authority because it is exercised hierarchically.

From a pedagogical point of view, power in SM should come from influence because the principal is the leader of the school. After analysing the source and form of power in school culture, its dominant coalitions in the organization must be identified. In school, these are employees because they work together and have a lot of influence, even though they don't have much authority. In other words, employees are potential allies in the school management coalition.

Since the psychosocial climate refers to the perception of specific sets of events, procedures, and rules of organization, the role of the teacher's identity is extremely important. But, as can be seen from Table 1, the functions of OC and climate are two-way, the role of teacher identity is correlated with the identity of the organization. The teacher's image depends on the values and assumptions within the school (Table 2), as well as on the teacher's identity (Table 4). This identity construct was created in interaction with other employees of culture, climate, and management. And it is precisely this causality of employee identity and school identity that leads to a holistic way of looking at SM.

\subsection{Identity of the organization}

The identity of an organization depends on employees, which is especially evident in nonprofit organizations such as schools. Employees stand out here because they are the most important segment and include the first contact with service users. Employees in non-profit organizations, such as schools, find themselves in a conflict situation, torn between the desire to provide quality services (Grönroos, 2019, p. 781) and their own perception of management.

If there is a lack of management support in building and strengthening the service climate, it will have a negative impact on teachers, and ultimately on the service itself. It is obvious that managerial support is a precondition for teacher satisfaction and motivation, and its absence cannot be hidden from users and directly affects the dissatisfaction of all stakeholders.

Since the culture of the organization is deeply rooted in the employee's perception (Park \& Doo, 
2020 , p. 114), it is necessary to develop brand identity on cultural reputation, on the coherence between the brand of promise and the performance that employees provide (Braxton \& Lau-Gesk, 2020, p. 2369). Corporate identity is important for several reasons: it enables the creation of a corporate brand and image (Balmer \& Gray, 2003, p. 978), but also because of the strategic dimension of brand positioning in the minds of consumers.

The notion of corporate identity can be most simply presented as the brand characteristics that the organization represents. Corporate identity is the foundation for building the corporate image of a school. Given that services in the school are characterized by indivisibility, the presence of users at the place of service, a high level of perceived risk and several other activities that affect the amount of stress among teachers, these services need a management concept based on management support.

SM must pay attention to employee satisfaction and motivation, providing support, clear communication, and proper delegation of responsibilities. In this way, management can create a favourable work climate and the overall environment. Corporate identity is a multidimensional construct because it encompasses different aspects of the organization, such as: strategy, corporate image, corporate culture, and corporate personality of the brand, all of which interact together.

Let us show the behaviour of principals and teachers from the aspect of SM and climate. The importance of employees in SM is unquestionable. Teachers are the most important resource of the school. Their role, in addition to educational and social, stems from the creation of a cultural community. Providing the service creates positive impressions on users and all stakeholders. Satisfied customers, stakeholders, employees thus promote their organization. As a result, the school becomes recognizable by teachers rather than by equipment, computers, or other technical aids. Teachers are the most important component of SM.

Also, such an understanding of SM creates the image of a corporation. However, image as a perceptual creation (Keller, Aperia \& Georgson 2008, p. 42-56) depends on identity. Corporate identity is created by employees. If their identity is positive, then it will be reflected in positive images in the consumer. Employees build a corporate identity through their work, quality of service, CRM, and OC.
According to Balmer (2001a, 2001b), this identity can be represented by the acronym $\mathrm{AC}^{2} \mathrm{ID}$ Test (see Table 5). The distinctions between identities presented by the $\mathrm{AC}^{2} \mathrm{ID}$ Test model are designed to enable strategic leadership and management of the corporate brand and at the same time as a diagnostic of planning and analysing existing segments of identity.

Table 5. AC ID Test in SM

\begin{tabular}{l|l|l}
\hline Identity & Impact on SM & $\begin{array}{l}\text { Influence on the } \\
\text { teacher }\end{array}$ \\
\hline Actual & School structure & Employee self-image \\
\hline Communicated & School competitions & Service quality \\
\hline Conceived & School image & Employee reputation \\
\hline Ideal & School culture & Employee motivation \\
\hline Desired & School personality & Employee loyalty \\
\hline \multicolumn{2}{r}{}
\end{tabular}

As can be seen from Table 5, the dissonance between corporate identity and other factors may lead to potential risk. If actual identity reflects internal stakeholders, the principal's style, and the structure of the school, it manifests itself in employees and self-image. It can also affect the communicated identity as it is reflected in the quality of the service which, consequently, calls into question competition with other schools which, in line with corporate marketing, we view as an advertising model. Of course, the image of the school is projected on the reputation of the employees and vice versa.

Therefore, the employee's relationship within the collective depends on SM, but also on the development of OC. The AC ${ }^{2}$ ID Test model serves as a strategic mechanism by which different identities within a corporation can be detected. However, for management to be successful, a synergy between employees, management, and school culture is needed.

\subsection{The role of teachers during COVID-19}

Since the outbreak of the COVID-19 pandemic, educational institutions have implemented a remote teaching model. It was a big step away from the previous way of teaching. Organizational support from management and ICT played a major role. It was a test of school culture and school climate. Organizational culture consisting of cognitive levels (see Table 2) has been reduced to a hybrid form of communication.

Opportunities that arose relate to expand traditional knowledge and skills in ICT, supportive agents, but also threats related to the lack of faceto-face teaching (Escobar \& Morrison, 2020, p.597). The strength of OC is manifested in the 
willingness of teachers to participate in a new, remote teaching model and share their teaching materials.

The pandemic has encouraged new innovative and creative teaching methods using ICT (Ellis, Steadman \& Mao, 2020, p. 562). Despite the traumatic circumstances of the pandemic, remote teaching took place at all educational levels (Cutri, Mena \& Whiting, 2020, p.524).

From a teacher perspective, the strongest constructs were the desire to learn and develop creativity. The weakest constructs were teaching contents that were often extensive and inappropriate for distance learning and doubts about the remote teaching model (Cutri et al., 2020, p. 528).

It is proposed to reconceptualise in the future through three core themes: a) care, b) control and c) power (Murray et al, 2020, pp. 491-497). However, the proposed models only further confirm that school culture is based on teachers' cultural habits and experiences. Remote teaching does not allow classroom control, and neither does mentoring (see Table 6).

Table 6. School culture during COVID-19 pandemic

\begin{tabular}{l|l}
\hline Symptoms & School culture during COVID-19 pandemic \\
\hline Remote teaching & Empty school: e-books, e-library \\
\hline No relationship & No class control, no travel \\
\hline $\begin{array}{l}\text { Teacher } \\
\text { vulnerability }\end{array}$ & Social and collaborative components \\
\hline
\end{tabular}

The forced transition from face-to-face to remote teaching, i.e., emergency eLearning (Murphy, 2020, p. 492) emphasized even more the importance of organizational culture and teachers. Therefore, the importance of social and collaborative components of learning and partnership with the organization is increasingly emphasized.

From the aspect of teaching and learning in the context of teacher education, three factors of distance learning are important (Carrillo \& Flores, 2020, p. 477): social presence, teaching presence, and cognitive presence.

COVID-19 presented significant challenges for managers (Spicer, 2020, p.1738) and the question arises: What happens when an OC dies? (Spicer, 2020, p.1739). Judging by the theoretical model, we can confirm that during the pandemic, the values of school culture (rituals, myths, and ceremonies) were partially lost, while assumptions (norms, rules) were retained, and events became hybrid.
The role of school culture, in the context of school functioning during the COVID-19 pandemic, has confirmed in theory and practice that teachers are the most important resources of any educational institution. Their way of working, behaviour, collegiality, support, and expertise have proven that despite the developed ICT system; they still represent the most important segment of the organization

\section{Conclusion}

Employees are the most important resource of any organization. The role of employees is very important because employees are a key element of the marketing mix in service industries such as schools. The image of an organization is created by employees who are in contact with others.

However, due to the very specificity of SM, employees differ from other employees in nonprofit organizations. This means that their skills, knowledge, and other abilities are very specific. After all, this is the only element that guarantees success to non-profit organizations.

School is, metaphorically speaking, a living organism. Due to numerous social, cultural, and economic changes, the role of the school is constantly being redefined. Thus, the school, as a non-profit organization, becomes specific because it opens new questions in the field of SM, but also HR. However, it should be noted that each school is at the same time an organization, which, in addition to educational values, is strongly dependent on OC, climate and employees.

Based on the results of certain dimensions of the school climate, a successful manager will strive to achieve an open climate because such a manager has personal integrity, high consideration, and thanks to interpersonal skills does not have to emphasize productivity, but completely controls the organization. Also, such a form leads to satisfied and motivated employees, and most importantly, a satisfied employee is created.

School is characterized by exceptional susceptibility to organizational values, norms, stereotypes, traditions, standards, ceremonies, and rituals and this should not be taken as something bad. This could be seen especially at the time of the COVID-19 pandemic when the role of teachers, school culture and school climate was put to the test.

The models of school culture listed in the paper proved to be vulnerable when it comes to the transition to remote teaching because all the burden was shifted to the teachers. Schools operated in a 
cold drive, losing the structure of rituals, myths and ceremonies that form the very core of the values of school culture. All events, rules and norms have adapted to the new circumstances.

Ultimately, during the COVID-19 pandemic, schools showed that the most important segment, along with students, was not expensive IT equipment, large halls, or rich libraries, but teachers themselves.sm

\section{References}

Andreasen, A., R., \& Kotler, P. (2008). Strategic Marketing for Non-Profit Organizations. London: Pearson, Prentice Hall.

Alvesson, M. (2002). Understanding Organizational Culture. London: Sage. https://doi.org/10.4135/9781446280072

Balmer, J. M. (2001a). Corporate identity, corporate branding and corporate marketing, seeing through the fog. European Journal of Marketing, 35(3/4), 248-291. https://doi.org/10.1108/03090560110694763

Balmer, J. M. T. (2001b). The three virtues and seven deadly sins of corporate brand management. Journal of General Management, 27(1), 1-17. https://doi.org/10.1177/030630700102700101

Balmer, J. M., \& Gray, E. R. (2003). Corporate brands: what are they? What of them? European Journal of Marketing, 37(7-8), 972-997. https://doi.org/10.1108/03090560310477627

Bolam, R. (1999). Educational administration, leadership and management: Towards a research agenda. In Bush, T., Bell, L., Bolam, R., Glatter, R., \& Ribbins, P. (Eds), Educational Management: Redefining Theory, Policy, and Practice (pp. 193-205). London: Sage. https://doi.org/10.4135/9781446219676.n15

Braxton, D., \& Lau-Gesk, L. (2020). The impact of collective brand personification on happiness and brand loyalty. European Journal of Marketing, 54(10), 2365-2386. https://doi.org/10.1108/EJM-12-2019-0940

Bush, T. (2003). Theories of Educational Management. London: Sage.

Bush, T. (2007). Educational leadership and management: theory, policy, and practice. South African Journal of Education, 27(3), 391-406.

Cameron, K. S., Quinn, R. E., DeGraff, J., \& Thakor, A. V. (2006). Competing values leadership: Creating value in organizations. Northampton, MA: Elgar.

Carrillo, C. \& Flores, M. A. (2020). COVID-19 and teacher education: a literature review of online teaching and learning practices. European Journal of Teacher Education, 43(4). 466-487. https://doi.org/10.1080/02619768.2020.1821184

Cutri, R. M., Mena, J. \& Whiting, E. F. (2020). Faculty readiness for online crisis teaching: transitioning to online teaching during the COVID-19 pandemic. European Journal of Teacher Education, 43(4), 523-541. https://doi.org/10.1080/02619768.2020.1815702

Day, C., Kington, A., Stobart, G., \& Sammons, P. (2006). The personal and professional selves of teachers: Stable and unstable identities. British Educational Research Journal, 32(4), 601-616. https://doi.org/10.1080/01411920600775316
Deshpande, R., \& Webster, F. (1989). Organizational culture and marketing: Defining the research agenda. Journal of Marketing, 53(1), 3-15. https://doi.org/10.2307/1251521

Deshpande, R., Farley, J., \& Webster, F. (1993). Corporate culture, customer orientation, and innovativeness in Japanese firms: A quadrat analysis. Journal of Marketing, 57(1), 23-37. https://doi.org/10.2307/1252055

Deshpande, R., \& Farley, J. (2004). Organizational culture, market orientation, innovativeness, and firm performance: An international research odyssey. International Journal of Research in Marketing, 21(1), 3-22. https://doi.org/10.1016/j.jiresmar.2003.04.002

Duan, X. J., Du, X. Y., \& Yu, K. (2018). School culture and school effectiveness: The mediating effect of teachers' job satisfaction. International Journal of Learning, Teaching and Educational Research, 17(5), 15-25. https://doi.org/10.26803/ij|ter.17.5.2

Ellis, V., Steadman, S. \& Mao, Q. (2020). Come to a screeching halt': Can change in teacher education during the COVID-19 pandemic be seen as innovation?. European Journal of Teacher Education, 43(4), 559-572. https://doi.org/10.1080/02619768.2020.1821186

Escobar, S.P. \& Astrid, M. (2020). Online teaching placement during the COVID-19 pandemic in Chile: challenges and opportunities. European Journal of Teacher Education, 43(4), 587-607. https://doi.org/10.1080/02619768.2020.1820981

Flores, M. A., \& Day, C. (2006). Contexts which shape and reshape new teachers' identities: A multi-perspective study. Teaching and teacher education, 22(2), 219-232. https://doi.org/10.1016/.tate.2005.09.002

Granjo, M., Silva, J. C. \& Peixoto, F. (2021). Teacher identity: can ethical orientation be related to perceived competence, psychological needs satisfaction, commitment and global self-esteem?. European Journal of Teacher Education, 44(2), 158-179. https://doi.org/10.1080/02619768.2020.1748004

Grönroos, C. (2019), Reforming public service: does service logic have anything to offer? Public Management Review, 21(5), 775-788. https://doi.org/10.1080/14719037.2018.1529879

Grönroos, C. (2020). Viewpoint: service marketing research priorities. Journal of Services Marketing, 34(3), 291298. https://doi.org/10.1108/JSM-08-2019-0306

Guion, R., M. (2011). Assessment, Measurment, and Prediction for Personnel Decisions (2nd ed.). London: Routledge. https://doi.org/10.4324/9780203836767

Hartnell, C., A., Ou, A., Y. \& Kinicki, A. (2011). Organizational culture and organizational effectiveness: a Meta-analytic investigation of the competing values. Journal of Applied Psychology, 96(4), 677-694. https://doi.org/10.1037/a0021987

Halpin, A. W. (1966). Theory and Research in Administration. New York: The Macmillan Company.

Holland, D., \& Lachicotte, W. (2007). Vygotsky, Mead, and the new sociocultural studies of identity. In $\mathrm{H}$. Daniels, M. Cole, \& J. Wertsch (Eds) The Cambridge Companion to Vygotsky (101-135). Cambridge: Cambridge University Press. https://doi.org/10.1017/CCOL0521831040.005 
Hoy, W. K., Tarter, C. J., \& Kottkamp, R. B. (1991). Open Schools / Healthy Schools: Measuring Organizational climate. Newbury Park: Sage Publications.

Hoy, W. K., \& Miskel, C. G. (2012). Educational Administration: Theory, Research, and Practice. $\left(9^{\text {th }}\right.$ ed.). New York: McGraw-Hill.

Huczynski, A. A., \& Buchanan, D. A. (2007). Organizational Behaviour. Harlow: Prentice Hall Financial Time.

Jukić, D. (2017). The importance of corporate branding in school management, International Journal of Strategic Management and Decision Support Systems in Strategic Management, 22(4), 11-18.

Jukić, D. (2019). Strategic Analysis of Corporate Marketing in Culture Management. International Journal of Strategic Management and Decision Support Systems in Strategic Management, 24(1), 10-18. https://doi.org/10.5937/StraMan1901010J

Kapferer, J. N. (2008). The New Strategic Brand Management. London: Kogan Page

Kelchtermans, G. (1993). Getting the story, understanding the lives: From career stories to teachers' professional development, Teaching and Teacher Education, 9(5/6), 443-456. https://doi.org/10.1016/0742-051X(93)90029-G

Kelchtermans, G. (1996). Teacher vulnerability: understanding its moral and political roots. Cambridge Journal of Education, 26(3), 307-324. https://doi.org/10.1080/0305764960260302

Keller, K. L., Aperia, T., Georgson, M. (2008). Strategic Brand Management. London: Pearson.

Korthagen, F. A. J. (2004), In search of the essence of a good teacher: Towards a more holistic approach in teacher education, Teaching and Teacher Education, 20, 77-97.

https://doi.org/10.1016/j.tate.2003.10.002

Kızıloğlu, M. (2021). The impact of school principal's leadership styles on organizational learning: Mediating effect of organizational culture. Business \& Management Studies: An International Journal, 9(3), 821-834. https://doi.org/10.15295/bmij.v9i3.1814

Lee, D. (2020). Impact of organizational culture and capabilities on employee commitment to ethical behavior in the healthcare sector. Service Business, 14(1), 47-72. https://doi.org/10.1007/s11628-019-00410-8

Morris, A., \& Bloom, J. R. (2002). Contextual factors affecting job satisfaction and organizational commitment in community mental health centres undergoing system changes in the financing of care. Mental Health Services Research, 4(2), 71-83. https://doi.org/10.1023/a:1015248116246

Mullins, L. J. (2006). Essentials of Organizational Behaviour. Harlow: Prentice Hall Financial Time.

Murphy, M. P. A. (2020). COVID-19 and emergency eLearning: Consequences of the securitization of higher education for post-pandemic pedagogy. Contemporary Security Policy, 41(3), 492-505. https://doi.org/10.1080/13523260.2020.1761749

Murray, C., Heinz, M., Munday, I., Keane, E., Flynn, N., Connolly, C., Hall, T. \& MacRuairc, G. (2020). Reconceptualising relatedness in education in 'Distanced' Times. European Journal of Teacher Education, 43(4), 488-502. https://doi.org/10.1080/02619768.2020.1806820
Nowak, R. (2020). Does employee understanding of strategic objectives matter? Effects on culture and performance. Journal of Strategy and Management, 13(4), 477-493. https://doi.org/10.1108/JSMA-02-2020-0027

Park, S. \& Doo, M. Y. (2020). The effect of organizational culture and HR practices on female managers' commitment and job satisfaction. European Journal of Training and Development, 44(2/3), 105-120. https://doi.org/10.1108/EJTD-03-2019-0045

Parker, M. (2000). Organizational Culture and Identity. London: Sage.

Peterson, K. D., \& Costner, S. (2006). Encyclopedia of educational leadership and administration. In English, F. W. (Ed), Encyclopedia of Educational Leadership and Administration (249-50). London: Sage.

Ployhart, R., E., Hale, D., Jr., \& Campion, M., C. (2014). Staffing within the social context. In Schneider, B. \& Barbera, K. M. (Eds.), The Oxford Handbook of Organizational Climate and Culture (pp. 23-44). Oxford: University Press.

Robbins, S. P., \& Coulter, M. (2005). Management. New Jersey: Upper Saddle River, Pearson Prentice Hall.

Slater, S. F., Olson, E.M. \& Finnegan, C. (2011). Business strategy, marketing organization culture, and performance. Mark Lett, 22, 227-242. https://doi.org/10.1007/s11002-010-9122-1

Schein, E. H. (1985). Organizational Culture and Leadership. San Francisco: Jossey-Bass.

Schneider, B., Gonzalez-Roma, V., Ostroff, C., \& West, M.A. (2017). Organizational climate and culture: reflections on the history of the constructs. Journal of Applied Psychology, 102(3), 468-482. https://doi.org/10.1037/apl0000090

Song J. H., Kim H. M., Kolb J. A. (2009), The effect of learning organization culture on the relationship between interpersonal trust and organizational commitment, Human Resource Development Quarterly, 20(2), 147-167. https://doi.org/10.1002/hrdq.20013

Spicer, A. (2020). Organizational Culture and COVID-19. Journal of Management Studies, 57(8), 1737-1740. https://doi.org/10.1111/joms.12625

Stacey, D. R. (1993), Strategic Management and Organizational Dynamics. Harlow: Prentice Hall Financial Time.

Stoll, L., \& Fink, D. (1996). Changing our schools: Linking school effectiveness and school improvement: Open University Press.

Wallace, M., \& Weindling, D. (1999). Overview of a group of research project with relevance to school management. In T. Bush, L. Bell, R. Bolam, R. Glatter, P. Ribbins (Eds). Educational Management: Redefining Theory, Policy and Practice, (206-218). London: Paul Chapman Publishing. https://doi.org/10.4135/9781446219676.n16

Williams, R. (2015). Keywords: A Vocabulary of Culture and Society. New York: Oxford University Press. 


\section{$凶$ Correspondence}

\section{Dinko Jukić}

Trade and Commercial School "Davor Milas" Osijek Ivana Gundulića 38, 31000 Osijek, Croatia

E-mail: dinko.jukic1@skole.hr 